\title{
Google Earth Pro as a Learning Media for Mitigation and Adaptation of Landslide Disaster
}

\author{
Erni Suharini, Muhammad Hasim Ariyadi, and Edi Kurniawan
}

\begin{abstract}
The importance of the problem of disasters in Indonesia encourages the integration of disaster mitigation into learning in schools. One of the manifestations is the inclusion of disaster mitigation as part of geography subjects. However, the implementation of disaster mitigation learning still experiences several obstacles related to the use of instructional media that are less interactive. This study intended to determine the learning outcomes using the media-assisted inquiry model Google Earth Pro on the material of landslide disaster mitigation and adaptation. This research was conducted at the high school level in Magelang District by taking a sample of the MA (Islamic Senior High School) in Magelang Regency. The variables of this study are the Google Earth Pro and Powerpoint media as independent variables and student learning outcomes as the dependent variable. Data collection techniques used in this study were tests and questionnaires. Researcher used the t-test as a data analysis technique. Student learning outcomes of the experimental class increased by $0.34 \%$ while the learning outcomes of the control class experienced an increase of $0.2 \%$ and categorized into low criteria. Based on the Independent sample test in the equal variances, assumed section, it could be seen that the Sig. (2-tailed) is $\mathbf{. 0 0 1}$. This shows that there is a difference between the learning outcomes of two different types of media. The Google Earth Pro-based media has a higher influence on student learning outcomes.
\end{abstract}

Index Terms-Google earth pro, learning media, mitigation and adaptation.

\section{INTRODUCTION}

The development of an increasingly advanced era encourages many innovations in learning media, so that up to this day, the learning media are very varied [1]. The Sophisticated innovation in learning media will affect the quality of education in a country [2]. The learning media used in the 2013 curriculum are interactive media that can develop students' thinking power and support the learning process. The more rapid development of technology makes learning media more varied, so that teachers are now required to be able to choose media that is suitable with the subject matter. The media used in the learning process will determine the process and learning outcomes in class [3].

According to [4], teachers play a major role in educational development, especially those that are held formally in schools. The teacher also determines the success of students, especially in relation to the learning process. Teachers are the most influential component in creating quality educational

Manuscript received March 24, 2020; revised June 16, 2020. This work was supported in part by the Faculty of Social Sciences Universitas Negeri Semarang, Indonesia.

E. Suharini, M. H. Ariadi, and Edi Kurniawan are with Geography Department Universitas Negeri Smearang, Indonesia (e-mail: erni.suharini@mail.unnes.ac.id). processes and outcomes. Interactive and creative media could make students interested and pay attention when the teacher is delivering the subject matter. Vice versa, the incorrect media selection causes students to get bored and their attention shifts to other things.

Preliminary observations at the MA (Islamic Senior High School) in Magelang Regency from July 31 to September 14 2018 obtained data that the Geography subjects in schools had used the 2013 curriculum. However, in disaster mitigation learning, teachers only used pictures available in textbooks in Geography learning. Learning media available at the MA (Islamic Senior High School) in Magelang Regency are still limited. The current available media are PowerPoint, Maps, and Globe. PowerPoint media is a media that is often used because of its cheapness, practical, and easy to make. PowerPoint is a one-way learning media that allows students to be passive in learning.

The use of media that is not varied will certainly make students saturated so that it affects the level of student understanding of the material delivered through the media. Yet, according to Law Number 24 of 2007 concerning disaster management, it is said that disaster risk reduction must be integrated into the development process, one of which is in the education sector [5]. The school community is part of a public space with a high level of vulnerability in dealing with disasters as well as having a real role in building community resilience, including building a culture of citizen disaster preparedness [6]. In accordance with Law No. 35 of 2014 concerning Child Protection, children are parties that must be protected and at the same time need to be improved in their knowledge of disaster [7].

The benefits of learning disaster mitigation and adaptation are actually not only limited to knowledge for students in the city of Magelang, because the area is a zone prone to landslides. The success of learning in the classroom is expected to have a contribution in the mitigation and adaptation of landslides in Magelang. According [8], although not the only way, but learning in schools can be considered the most effective way to make people literate or aware earlier. Learning directly in schools can make students aware of disasters that could threaten their existence and their mitigation efforts. Furthermore, they can disseminate this knowledge to families and the wider community in their environment.

The landslides happen in Tanjungsari Village, Windusari Sub-district. Then, in the northern part of Magelang, precisely in Grabag Sub-district, which caused material and non-material losses, it reinforced the reasons why learning to mitigate and adapt to landslide disasters must be carried out optimally in class. The students have to understand the concept, one of which is the occurrence of ground 
movements that often occur are rock debris, land creeps, and avalanches of broken material [9]. Then, the students could participate in the community to socialize how dangerous it is to live in a landslide prone zone. BPBD (Indonesian National Board for Disasters) of Magelang Regency recorded at least 231 landslide disasters in the region, and in 2018 it increased to 352 landslide disasters [10].

Based on what has been described, improvements are needed in the use of instructional media, so students are more motivated and more active in studying Geography subjects. Then, the message conveyed can be received and understood properly so as to improve the learning outcomes. In addition to the benefits of learning outcomes, disaster mitigation and adaptation materials are very important for the Magelang area, which includes disaster-prone areas, especially landslides.

One effort that can be done is to use interactive learning media. Interactive learning media is expected to be able to assist teachers in delivering subject matter so that learning can be more interesting and effective. It would encourage students to understand the concepts of learning Geography easily [11]. The benefits of using interactive media are to expand and increase knowledge and train students' independence for creative and innovative thinking in learning Use this media can demonstrate a learning activity feels more alive, clarifying presentation of subject matter that is written or oral [12] The use of interactive media can increase the ability of students to analyze, criticize, and reach conclusions based on inference or careful consideration called critical thinking skills [13].

The interactive learning media are also flexible in adjusting to the speed of one's learning [14], [15]. The most important characteristic of this media group is that students do not only pay attention to the media or objects, but also required to interact while learning. There are at least three kinds of interactions. The first interaction is makes students interact with a program, for example students are asked to fill in blanks on programmed learning material. The second form of interaction is that students interact with machines, such as learning machines, simulators, language laboratories, computers, or a combination of them in the form of interactive videos. The third is to regulate interactions between students on a regular but not programmed basis. For example, it can be seen in various educational games or simulations that involve students in activities or problems, which require them to classify opponents' attacks or work together with teammates in solving problems [16].

The emergence of boredom of learning in students is caused by several factors, such as the students experiencing difficulties in learning. In general, students who have learning problems are afraid to express their knowledge. For that, teachers need to carefully understand students whose performance has declined [17]. A student who has a higher learning speed can complete his learning activities quickly. On the other hand, students with a slow learning speed can complete their learning activities in accordance with their respective speeds. This is very different from classical learning in class, where each student is forced to learn at a speed determined by the teacher. Students who have high learning speeds can feel bored, whereas students with low learning speeds feel that the learning process is too fast to follow [18].

Google Earth Pro is one of output products produced by Google in the form of software that is able to display a picture of the earth's surface both in two dimensions (2D) and three dimensions (3D). Google Earth Pro has several advantages compared to other earth surface views. For example, the users could see the surface of the earth from the desired direction. With the use of the Google Earth Pro media, it can show how the shape of the earth's surface, land use, and slope [19]. Using Google Earth Pro will save 38 hours rather than direct surveys in the field. MA in Magelang Regency has the potential to use Google Earth Pro media because of several factors [20].

One of the main factors that support the use of Google Earth Pro is the availability of internet services in every school building. Google Earth Pro is software that must be accessed by using an internet network, so a good internet network will facilitate the use of it. The computer laboratory facilities that are connected to the internet could be used as an alternative if the availability of computers or laptops in the classroom is inadequate. Students who are mostly from urban areas are also familiar with technological developments including the term Google. Certainly, it would be uncomfortable for the teachers to teach by using software if the students were less familiar with the term.

The use of Google Earth Pro media is able to provide solutions to the lack of variation in the use of instructional media. Google Earth Pro can be used passively or interactively. Students can be involved in the use of media in the learning process in class. The three-dimensional (3D) display of Google Earth Pro can build student enthusiasm for being able to see space interactively. Students can see a particular spatial phenomenon from their preferred angle and direction, so that the media presented can be seen as real thing and interesting.

The use of Google Earth Pro is not only limited to the analysis of current field conditions, but can also analyze the picture at past time that has been missed. Students can choose which areas will be seen while connected to the internet. Students are not only presented with the latest field conditions, but also the conditions a few years back.

An interactive display from Google Earth Pro is able to answer the problematic features of PowerPoint which tend to be passive. PowerPoint only display the spatial condition in the form of two-dimensional (2D) images, so that students' views and analysis are only limited to the images that are seen. Students in their daily learning are only receiving presentations from teachers. They are unable to be actively involved.

The use of Google Earth Pro media will be in line with the inquiry model learning flow. Inquiry learning model has constructive thinking characteristics, where students are invited to look for facts, then formulate problems, and find solutions to those problems [21]. The role of the teacher is very important as a facilitator. Because, teachers play a major role in educational development, especially those that are held formally in schools. The teacher also determines the success of students, especially in relation to the learning process. Teachers are the most influential component in creating quality educational processes and outcomes. Through these activities, students will master, apply, and find 
things that are useful for themselves [4].

\section{Methodology}

The populations in this study were all students of class XI-IPS in MAN (Islamic Senior High School) of Magelang Regency in the academic year of 2018/2019. The sampling technique is random sampling. The sample is divided into two types namely students of class XI IPS 3 as an experiment class, and students of class XI IPS 2 as a control class. The dependent variable in this study was student learning outcomes and the independent variables were Google Earth Pro and PowerPoint media. Data collection techniques used in this study are tests, and t-test as a data analysis technique.

\section{RESULT AND DISCUSSION}

MAN (Islamic Senior High School) of Magelang Regency is located at Jalan Raya Payaman number 1, Payaman Village, Secang Sub-district, Magelang Regency. This study entitled the model of inquiry learning assisted by Google Earth Pro media on geography subjects in MAN (Islamic Senior High School) of Magelang Regency in academic year of 2018/2019 conducted on May 13, 2019 to May 19, 2019.

The learning activity in the control class is using PowerPoint media, while the learning activity in the experimental class is using Google Earth Pro media. In the learning process of the control class, the researcher provides learning material about landslide disaster mitigation and adaptation. In class XI IPS 2, students are using PowerPoint with inquiry learning models. Then, the learning continues with group work with members totaling of 4 to 5 students.

In the learning activity in the experimental class, the researcher use Google Earth Pro media to display the appearance of landslide prone areas. By using Google Earth Pro, the appearance of the face of the earth can be seen in 3 dimensions (3D). Even by using Google Earth Pro, students can study the desired area. In this study, students were invited to study landslide disasters in Jemblung, Sampang Village, Karangkobar Sub-district, Banjarnegara Regency. The location was chosen because of its clear appearance in Google Earth Pro.

After using Google Earth Pro to identify the areas affected by landslides, the students are invited to analyze landslide disasters in the environment around students' homes. Both of them have been affected and areas prone to landslides. The students can use Google Earth Pro again to see the features to be discussed plus supplementary data from relevant sources. Then, the students can identify the areas prone to landslides, causes of landslides, and mitigation measures that must be taken. Analysis of the data at the initial stage is used to determine the initial ability of students in the experimental class and the control class before getting treatment.

TABLE I: PRETEST SCORE

\begin{tabular}{lllll}
\hline Class & $\mathrm{N}$ & Minimum & Maximum & Average \\
\hline Experiment & 36 & 44 & 84 & 69.6 \\
\hline Control & 32 & 44 & 92 & 68.8 \\
\hline Source: The analysis of research data
\end{tabular}

The data analysis includes normality test, homogeneity test, and t test (average difference test) whose data comes from the value of the pretest of control class and the experimental class. The results of the pretest scores from the experimental class and control class can be seen in Table I.

Based on the normality test of the pretest result, the $D_{\max }$ value for the control class was 0.094481 and the experimental class was $0.16383837 . K S_{\text {table }}$ value for the control class is 0.240416 and $K S_{\text {table }}$ for the experimental class is 0.236745612 . The $D_{\max }$ value in the control class is smaller than the $K S_{\text {table }}$ of the control class so that the pretest data of the control class is normally distributed. The $D_{\max }$ value in the experimental class is smaller than the $K S_{\text {oftable }}$ the experimental class that data pretest the experimental classis normally distributed. The results of the pretest score normality test analysis can be seen in Table II below.

TABLE II: NORMALITY TEST OF THE PRETEST RESULT

\begin{tabular}{ccc}
\hline & Experiment Class & Control Class \\
\hline$N$ Sample & 32 & 32 \\
\hline Mean & 70,8 & 69,2 \\
\hline Standart Deviation & 8,015107 & 7,496236 \\
\hline$D_{n}=$ & 0,16383837 & 0,094481 \\
\hline$K S$ Table & 0,236745612 & 0,240416 \\
\hline & Normal & Normal
\end{tabular}

Source: The analysis of research data

The homogeneity test results of pretest of the Control Class and Experiment Class known value of Sig. Based on Mean for student learning outcomes variable is 0.412 . Because the value of sig. 0.412>0.05, then as the basis for decision making in homogeneity above, it could be concluded that the variance of learning outcomes data between the experimental class and the control class is the same (homogeneous). The results of the analysis of the pretest scores homogeneity between the experimental class and the control class can be seen in Table III below.

TABLE III: T-TEST RESULTS OF PRETEST SCORE

\begin{tabular}{lc}
\multicolumn{2}{l}{ Independent Samples Test } \\
\hline \multicolumn{2}{l}{ Levene's Test for Equality of Variances } \\
\hline F. & 681 \\
\hline Sig. & .412 \\
\hline$t$-test for Equality of Means (Equal variances assumed) \\
\hline$T$ - & 291 \\
\hline Df & 63 \\
\hline Sig. (2-tailed) & .772 \\
\hline Mean Difference & -.822 \\
\hline Std. Difference Error & 2,822 \\
\hline 95\% Confidence Interval of the Difference \\
\hline Lower & $-6,462$ \\
\hline Upper & 4,818 \\
\hline Source: The analysis of research data
\end{tabular}

Based on the Table III, namely "Independent Samples Test" output in the "Equal variances assumed" section, the Sig. (2-tailed) of .772>0.05. Then, as the basis for decision making in the independent sample $t$ test, it can be concluded that HO is accepted. Thus, it can be concluded that there is no significant difference between the average learning outcomes in the control class and the experimental class.

This final stage of data analysis is to determine the ability of students after getting treatment. This analysis uses the result of posttest of control and experimental classes. The control class was treated by using PowerPoint media, while the experimental class used Google Earth Pro media. The 
data analysis includes normality test, homogeneity test, $\mathrm{t}$ test, and test of learning achievement improvement. The results of the posttest scores from the experimental class and control class can be seen in Table IV below.

TABLE IV: POSTTEST SCORE

\begin{tabular}{lllll}
\hline Class & $\mathrm{N}$ & Minimum & Maximum & Average \\
\hline Experiment & 32 & 68 & 94 & 80.81 \\
\hline Control & 32 & 64 & 84 & 75.75 \\
\hline Source: The analysis of research data & &
\end{tabular}

Based on the normality test of posttest, the Dvalue $_{\max }$ for the control class was 0.2071496 and the experimental class was 0.156261 . The $K S_{\text {table }}$ value for the control class is 0.240416 and the $K S_{\text {table }}$ for the experimental class is 0.240416 . The value of $D_{\max }$ in the control class is smaller than the $K S_{\text {oftable }}$ the control class, so the posttest data of the control class is normally distributed. $D_{\max }$ value in the experimental class is smaller than $K S_{\text {table }}$ of the experimental class, so the posttest data of the experimental class is normally distributed. The results of the posttest score normality test analysis can be seen in Table $\mathrm{V}$ below.

TABLE V: NORMALITY TEST OF THE POSTTEST RESUlt

\begin{tabular}{ccc}
\hline & Experiment Class & Control Class \\
\hline N Sample & 32 & 32 \\
\hline Mean & 80,8125 & 75,75 \\
\hline Standart Deviation & 6,19801 & 5,0736511 \\
\hline$D_{n}=$ & 0,156261 & 0,2071496 \\
\hline$K S$ Table & 0,240416 & 0,240416 \\
\hline & Normal & Normal
\end{tabular}

The results of the Homogeneity Test of the posttest of Control Class and Experiment Class are known to be Sig. Based on Mean for student learning outcomes variable is equal to 0.073 . Because the value of sig. $0.073>0.05$, then as the basis for decision making in homogeneity above, it can be concluded that the variance of learning outcomes data between the experimental class and the control class is the same (homogeneous). The results of the analysis of the posttest scores homogeneity between the experimental class and the control class can be seen in Table VI below.

TABLE VI: T-TEST RESULTS OF POSTTEST SCORE

\begin{tabular}{lc}
\multicolumn{3}{l}{ Independent } \\
\hline \multicolumn{2}{l}{ Levene Test for Variant Equations } \\
\hline $\mathrm{F}$ & 3,337 \\
\hline Sig. & .073 \\
\hline$T$-test for the mean equation (Variants are assumed to be the same) \\
\hline$T$ & 3,575 \\
\hline $\mathrm{Df}$ & 62 \\
\hline Sig. (2-tailed) & .001 \\
\hline Mean Difference & 5,063 Std. \\
\hline Error Difference & 1,416 \\
\hline 95\% confidence interval from the difference of \\
\hline Lower & 2,232 \\
\hline Upper & 7,893 \\
\hline Source: The analysis of research data
\end{tabular}

Based on the Table VI, namely "Independent" output in the "variance assumed to be the same" section known that the value of Sig. (2-tailed) of $.001<0.05$. As the basis for decision making in the independent sample $t$ test, it could be concluded that $\mathrm{H} 0$ is rejected and $\mathrm{H} 1$ is accepted. Thus, it can be concluded that there are significant (real) differences between the average learning outcomes in the control class and the experimental class.

Based on the results of the analysis of the N-Gain test, it can be obtained that the learning outcomes of the experimental class and the control class have increased differently. The experimental class increased by $0.34 \%$. It means that the increase included in moderate criterion. On the other hand, in the control class there was an increase of $0.2 \%$. It means that it was included in the low criteria.

From the results of the study, it was seen that there were differences in learning outcomes by using Google Earth Pro and PowerPoint media. The N-Gain Test shows that the increase in experimental class learning outcomes is higher than the control class. It could be concluded that the use of Google Earth Pro media is more effective than the PowerPoint media.

In the student questionnaire responses to the use of the Google Earth Pro media, there are five indicators (the presentation, content, language, learning process, and student interest) which are broken down into 20 questions and given to class XI IPS 3. Based on the results of the questionnaire on class XI IPS 3, the highest average percentage indicator is Content indicator with the total of $81.4 \%$. The second is the learning process indicator by $80.7 \%$. The indicator of student interest is $74.6 \%$, the presentation indicator is $73.9 \%$, and the last is the language indicator by $65,9 \%$. Thus, it can be concluded that the average percentage of students' responses to the questionnaire of Google Earth Pro media for all indicators was $75.3 \%$. It can be concluded that the criteria of Google Earth Pro media according to students' responses are interesting.

In the students' questionnaire responses to the use of the PowerPoint media, there are five indicators (namely the presentation, content, language, learning process, and student interest) indicators which are broken down into 20 questions and given to class XI IPS 2. Based on the results of the questionnaire on class XI IPS 2, the highest average indicator is Language at $63.6 \%$. The second is the student interest indicator at $62.1 \%$, the presentation indicator is $61.4 \%$, the learning process indicator is $60.8 \%$, and the last is the content indicator with $58.7 \%$. Thus, the average percentage of students' responses to the questionnaire for PowerPoint media for all indicators was $61.32 \%$. It can be concluded that the criteria of PowerPoint media according to students' responses are less attractive.

After the learning process is done, then learner understanding is measured. There is an increase in the value of learning outcomes, but an increase in learning outcomes between the control class and the experimental class is different. The test results on the average difference between posttest the experimental class and the control class is 0.01 . It showed a significant difference in the learning outcomes.

The Significant differences in learning outcomes of posttest between the control class and the experimental class show that the experimental class with Google Earth Pro media is more effective than the control class that uses PowerPoint media. The test results of increasing the learning outcomes in the experimental class fall into the medium category, while the increase in learning outcomes in the control class fall into the low category. Thus, it can be seen 
that the use of the Google Earth Pro media as a learning medium for landslide disaster mitigation and adaptation materials can help facilitate students in understanding learning material. According to research Kurniawan [22] development young generation to aware in disaster and environmental is very important, and this research is one strategy to increase millennial to aware in disaster. Young generation must aware for protecting their environment, because there were many pollution can reduce environment quality [23]-[26].

\section{CONCLUSION}

Based on the results of research that has been done, it can be concluded that 1 . The results of geography learning by using Google Earth Pro media on basic competencies of Mitigation and Adaptation of Disasters, sub-subject of Mitigation and Adaptation of Landslides in class XI IPS I in MAN Magelang Regency has an average posttest of 80.81 with a pretest value of 70.8 . The improvement of the learning outcomes in the experimental class is $0.34 \%$, and included in the medium criteria.

The learning outcomes of geography by using PowerPoint media on the basic competencies of Mitigation and Adaptation of Disasters, sub-subject Mitigation and Adaptation of Landslides in class XI IPS III in MAN of Magelang Regency has an average posttest of 75.75 with a pretest value of 69.2. The improvement of the learning outcomes in the control class is $0.2 \%$ and included low criteria.

The results showed a difference in learning outcomes between the experimental class and the control class. The two $\mathrm{t}$ test/difference in the average known value of Sig. (2-tailed) of .001<0.05, so as the basis for decision making in the independent sample $\mathrm{t}$ test, it can be concluded that $\mathrm{H} 0$ is rejected and $\mathrm{H} 1$ is accepted. Thus, it can be concluded that there are significant (real) differences between the average learning outcomes in the control class and the experimental class.

Based on the conclusions above, the suggestion proposed in this research is that it is expected that the Google Earth Pro media can be used as an alternative media in learning geography. It is done so that the learning process is more fun, improving teacher skills, increasing learning activities, and student learning outcomes. Teachers can use innovative and interactive media so that learning geography is more concrete and makes it easier for students to understand the learning process. Other researchers can apply similar research by perfecting optimally so that it can be useful to improve the quality of geography learning.

\section{CONFLICT OF INTEREST}

The authors declare no conflict of interest.

\section{AUTHOR CONTRIBUTIONS}

In this study, each author has different contribution. The first author contributes to planning research, designing research procedures and methods, and conducting data collection. The second author has contributed to collecting research data and analyzing data. Then, the third author contributes to the analysis of research data and write a research report and writes a paper for publication.

\section{ACKNOWLEDGMENT}

Thank to Faculty of Social Sciences Universitas Negeri Semarang to all procedure of research step.

\section{REFERENCES}

[1] U. Muslikhah and L. Rahmasari, "Befizel, learning physics by using puzzle as learning media innovation," in Proc. the International Conference on Teacher Training and Education, vol. 1, no. 1, January 2016.

[2] S. Syahroni and M. Nurfitriyanti, "Pengembangan media pembelajaran interaktif berbasis komputer dalam pembelajaran matematika, materi bilangan pada kelas 3 SD," Formatif: Jurnal Ilmiah Pendidikan MIPA, vol. 7, no. 3, 2018.

[3] M. H. Furqan, E. Maryani, and M. Ruhimat, "Innovation learning: Audio visual and outdoor study to enhance student's understanding of disaster," Innovation of Vocational Technology Education, vol. 13, no. 2, 2017.

[4] E. Suharini, "Studi tentang Kompetensi Pedagogik dan Profesional bagi Guru Geografi di SMA Negeri Kabupaten Pati,” Jurnal Geografi: Media Informasi Pengembangan dan Profesi Kegeografian, vol. 6, no. 2, 2011.

[5] Undang-undang Nomor 24 Tahun 2007 Tentang Upaya Penanggulangan Bencana di Indonesia, 2007.

[6] Consortium for Disaster Education Indonesia, A Framework of School-Based Disaster Preparedness, Jakarta: The Consortium for Disaster Education, 2011.

[7] Undang-undang Nomor 35 Tahun 2014 Tentang Perlindungan Anak, 2014.

[8] E. Suharini, D. L. Setyawati, and E. Kurniawan, "Pembelajaran kebencanaan bagi masyarakat di daerah rawan bencana banjir DAS Beringin Kota Semarang," Forum Ilmu Sosial, vol, 42, no. 2, pp. 184-195, 2015.

[9] W. Setyaningsih and M. Sholeh, "Pemetaan daerah rawan bencana gerakan tanah di wilayah Grabag Kabupaten Magelang Propinsi Jawa Tengah," Sainteknol: Jurnal Sains dan Teknologi, vol. 8, no. 1, 2010.

[10] R. Ferry. (2018). Tanah longsor dan angin kencang mengintai di musim hujan. [Online]. Available: https://jogja.tribunnews.com/2018/10/30/bpbd-kabupaten-magelang-t anah-longsor-dan-angin-kencang-mengintai-di-musim-hujan

[11] A. Arda, "Pengembangan media pembelajaran interaktif berbasis komputer untuk siswa SMP Kelas VIII," Mitra Sains, vol. 3, no. 1, 2015.

[12] R. M. Putri, E. Risdianto, and N. Rohadi, "Pengembangan media pembelajaran interaktif dengan menggunakan adobe captivate pada materi gerak harmonik sederhana," Jurnal Kumparan Fisika, vol. 2, no. 2, pp. 113-120, 2019.

[13] Z. Zulhelmi, A. Adlim, and M. Mahidin, "Pengaruh media pembelajaran interaktif terhadap peningkatkan keterampilan berpikir kritis siswa," Jurnal Pendidikan Sains Indonesia (Indonesian Journal of Science Education), vol. 5, no. 1, pp. 72-80, 2017.

[14] N. Nopriyanti and P. Sudira, "Pengembangan multimedia pembelajaran interaktif kompetensi dasar pemasangan sistem penerangan dan wiring kelistrikan di SMK," Jurnal Pendidikan Vokasi, vol. 5, no. 2, pp. 222-235, 2015.

[15] D. Y. Saputri and M. I. Rukayah, "Integrating game-based interactive media as instructional media: students' response," Journal of Education and Learning (EduLearn), vol. 12, no. 4, pp. 638-643, 2018.

[16] D. Tarigan and S. Siagian, "Pengembangan media pembelajaran interaktif pada pembelajaran ekonomi," Jurnal Teknologi Informasi \& Komunikasi Dalam Pendidikan, vol. 2, no. 2, 2015.

[17] M. Muzkan, H. Hasmunir, and T. Kamaruddin, "Perbandingan hasil belajar siswa menggunakan media pembelajaran powerpoint dengan konvensional," Jurnal Ilmiah Mahasiswa Pendidikan Geografi Unsyiah, vol. 1, no. 1, 2016.

[18] L. Lingin, "Pengembangan media pembelajaran interaktif pada mata pelajaran Geografi," Jurnal Geografi, vol. 4, no. 2, pp. 15-28, 2012.

[19] ESRI. (2019). About Google Earth Pro Mapping \& Analytics Platform. [Online]. Available: https://www.esri.com/en-us/Google Earth Pro/about-Google Earth Pro/overview

[20] B. T. Taylor, P. Fernando, A. E. Bauman, A. Williamson, J. C. Craig, and S. Redman, "Measuring the quality of public open space using Google Earth," American Journal of Preventive Medicine, vol. 40, no. 2, pp. 105-112, 2011. 
[21] S. D. Setiasih, "Penggunaan model inkuiri untuk meningkatkan hasil belajar siswa pada materi sifat-sifat magnet di kelas v SDN Sukajaya Kecamatan Jatinunggal Kabupaten Sumedang,” Doctoral dissertation, Universitas Pendidikan Indonesia, Bandung, Indonesia, 2016.

[22] E. Kurniawan et al., "Development strategy of cadres students on school based environmental and disaster awareness," in Proc. IOP Conf. Ser.: Earth Environ. Sci., 2019.

[23] H. Rahmayanti, V. Oktaviani, and Y. Syani, "Development of sorting waste game android based for early childhood in environmental education," Journal of Physics: Conference Series, vol. 1434, no. 1, 2020.

[24] H. Rahmayanti, I. Z. Ichsan, V. Oktaviani, Y. Syani, W. Hadi, and G. Marhento, "Environmental attitude for smart city technology: Need Assessment to develop smart trash in environmental education," International Journal of Advanced Science and Technology, vol. 29, no. 3, 2020.

[25] A. Harahap, A. Zuhriyah, and H. Rahmayanti, "Relationship between knowledge of green product, social impact and perceived value with green purchase behavior," Journal: E3S Web of Conferences, vol. 74, no. 4002, 2018.

[26] H. Rahmayanti, V. Oktaviani, and Y. Syani, "The implementation of smart trash as smart environment concept," Journal: E3S Web of Conferences, vol. 74, no. 6003, 2018.

Copyright (C) 2020 by the authors. This is an open access article distributed under the Creative Commons Attribution License which permits unrestricted use, distribution, and reproduction in any medium, provided the original work is properly cited (CC BY 4.0).

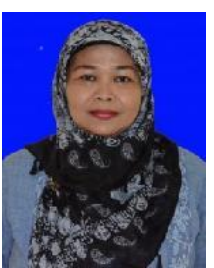

Erni Suharini is an associate professor in the field of geography education, especially in environmental education. Erni wrote a number of books and articles in the field of geography, especially environment and disaster. Erni Suharini has served as a lecturer of no less than 25 years with extraordinary experience in research, service and education.

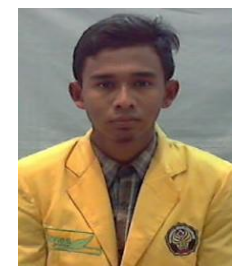

M. Hasim Ariadi is a graduate of geography at Semarang State University. During his time as a student, Ariyadi actively participated in activities related to the education based technology and scout. Related in the field of study he always read and wrote about education absed on technology.

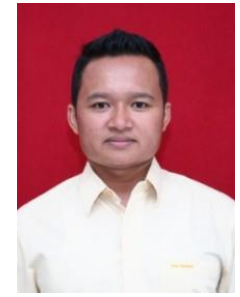

Edi Kurniawan is a lecturer at the Geography Department of UNNES who began his career in 2011 His focus on community-based research has come to his attention and he has written several articles published in international journals. He is a reviewer of Scopus indexed International Journal and National Journal in Indonesia. 